\title{
Acute effect of metipranolol on the retinal circulation
}

\author{
Sebastian Wolf, Eva Werner, Karin Schulte, Martin Reim
}

\begin{abstract}
Aim-To assess the effect of topical and systemic application of a $\beta$ adrenergic receptor blocker on retinal haemodynamics.

Methods-24 healthy subjects were included in this double masked, randomised, placebo controlled crossover study. Metipranolol, a non-selective $\beta$ adrenergic receptor blocking agent was used as test drug. In all subjects armretina time, arteriovenous passage time, arterial mean dye velocity, the arterial vessel diameters, and capillary flow velocity were quantified from digital video fluorescein angiograms.
\end{abstract}

Results-A significant effect was observed on the arteriovenous passage time $(\mathrm{p}<0.05)$, the arterial mean dye bolus velocity $(p<0.05)$, and capillary blood velocity $(p<0.05)$, but not on the arterial vessel diameter. The arterial mean dye bolus velocity and capillary blood velocity increased after application of the test drug (topical and systemic). In tandem with this a decrease of the arteriovenous passage time was observed. The perfusion pressure increased after topical application and remained unchanged after systemic application of metipranolol.

Conclusions-This study shows that systemic as well as topical application of metipranolol leads to increased retinal blood flow velocities. The implications of these results for treatment with $\beta$ adrenergic receptor blockers is not clear. However, in view of these data it is very unlikely that treatment with metipranolol has a negative effect on retinal blood flow. (Br f Ophthalmol 1998;82:892-896)

Augenklinik der Medizinischen,

Fakultät der

Rheinisch-Westfälischen

Technischen

Hochschule Aachen,

Aachen, Germany

$S$ Wolf

E Werner

K Schulte

M Reim

Correspondence to:

Dr S Wolf, Augenklinik der

Med Fak der RWTH,

Aachen, Pauwelsstrasse 30,

D-52057 Aachen, Germany.

Accepted for publication

4 March 1998

Recently the effect of medications used for glaucoma therapy on ocular blood flow has become an area of increased interest. ${ }^{1-8}$ The effect of $\beta$ adrenergic receptor blocking agents is of particular concern with regard to drugs used for long term therapy, as is the case with primary open angle glaucoma. Several studies showed either a positive, ${ }^{3-69}$ or negative $e^{1210}$ effect of topical application of $\beta$ adrenergic receptor blockers on the retinal circulation.

The decrease in intraocular pressure is known to be a side effect of systemic applications of $\beta$ adrenergic receptor blockers. ${ }^{11}$ There is no information about the influence of systemic $\beta$ adrenergic receptor blockers on the retinal circulation. In the current study we investigated the acute effect of topical as well as of systemic application of metipranolol on the retinal circulation.

Metipranolol, a non-selective $\beta$ adrenergic receptor blocking agent is used systemically for the treatment of arterial hypertension and topically for the management of glaucoma patients. The systemic hypotensive effect of this drug is achieved through a decrease in the $\beta$ sympathetic tone and cardiac output. ${ }^{12}$ Intraocular pressure is lowered by a decrease in the rate of aqueous humour formation. ${ }^{13}$

\section{Subjects and methods}

Twenty four healthy subjects (12 males, 12 females) aged 24-34 years were included in this double masked, randomised, placebo controlled crossover study. Histories, physical examination, electrocardiograms, and routine chemical analyses showed that the volunteers had no evidence of present or past hypertension, cardiovascular disease, or any other systemic condition and were taking no medications except for oral contraceptive drugs. All subjects had normal visual acuity and minimal or no refractive error. All participants gave written informed consent for all procedures. This study was approved by the local review board.

\section{PROTOCOL}

All studies were performed in the morning. One eye from each study participant was randomly selected to be studied at each session. Commercially available metipranolol eye drops (Betamann 0.3\%) and tablets (Disorat 10) were used. Artificial tears were used as topical placebo, and lactose tablets were used as systemic placebo. The test drugs were provided by Dr Mann Pharma, Berlin, Germany. All study participants (subjects and observers) were masked throughout the study. Only after finishing all measurements was the code broken for statistical analysis.

At each session, the subjects received either topical or systemic treatment with metipranolol or placebo. The time interval between each of the four sessions was 2 weeks. All examinations were performed before the application of the test substance and 2 hours thereafter. Examinations included video fluorescein angiography, measurement of intraocular pressure, blood pressure, and heart rate.

In all study eyes a video fluorescein angiogram was performed using a scanning laser ophthalmoscope (SLO; Rodenstock Instruments, Germany) after intravenous injection of $2.5 \mathrm{ml}$ sodium fluorescein $(10 \%)$ with a $10 \mathrm{ml}$ saline flush.

Digital picture analysis of video fluorescein angiograms allows for quantitative assessment 
of retinal circulation. Retinal macrocirculation can be characterised by the arm-retina time, the arteriovenous passage time, arterial mean dye velocity, and the arterial vessel diameters. In contrast, the measurement of capillary flow velocity provides data on retinal microcirculation. Macrocirculatory measurements are carried out in the 40 degree observation field. This mode allows for imaging the entire posterior pole. For the assessment of capillary flow velocities high definition angiograms of the perifoveal capillary network are necessary. Therefore, the 20 degree field of the SLO is used. For all measurements the video signal generated by the SLO is converted into digital information and recorded on an image sequence storage unit. The method is presented in detail elsewhere. ${ }^{14}$

For the measurement of retinal macrocirculation, density variations in the SLO generated fluorescein angiograms were analysed by means of digital image processing system. Firstly, the angiograms were corrected for eye movements based on a recursive estimation method, described in detail elsewhere. ${ }^{15}$ After correction for eye movements, the digital image processing system measures the entire angiogram sequence, recording the intensity of fluorescein at various locations. Six points (size $3 \times 3$ pixels) were interactively selected for measurement. The computer then analysed the entire angiogram frame by frame. Fifty frames per second were evaluated. For each image, the program recorded the mean intensity levels at each of the six selected locations. Intensity curves were obtained by plotting the collected data against the time axis. The time of the first appearance of fluorescein was evaluated from the intensity curves. According to the location of the measuring points several variables of retinal circulation were assessed.

Two points were selected for measurement on the superotemporal and inferotemporal arteries 0.5 disc diameter from the disc margin. Two more distally located points, two disc diameters from the disc margin on each artery were similarly monitored. The differences in appearance time and the actual distance between the proximal and distal marking point at each artery were used for calculation of the mean arterial dye velocity. The time elapsed between the appearance of dye at the proximal reference point at the temporal arteries and an adjacent point at its corresponding vein was used to determine the arteriovenous passage times.

Finally, the vessel diameters were quantified for the temporal retinal arteries using the half high method. ${ }^{16-18}$ For these measurements monochromatic images centred on the optic nerve head were recorded using the 20 degree field of the SLO. Reproducibility of this measuring technique is about $3 \%{ }^{19}$ All diameter measurements were carried out 0.5 disc diameter from the disc margin. The data obtained from the superior and inferior temporal quadrant were averaged for each patient in order to obtain representative values for the posterior pole and not only for one temporal quadrant.
For measurement of retinal microcirculation the 20 degree field of the SLO is used. In these digital high definition angiograms, segments of low and high fluorescence can be observed moving through the perifoveal network. The sequences were processed off line to evaluate the mean capillary flow velocity and coefficient of variation of mean capillary flow velocity. The measurement of flow velocity is based on the determination of transit time " $\Delta \mathrm{t}$ " between two measuring points, separated by a known distance " $\Delta s$ ". The actual distance $\Delta s$ was measured by a digital image processing system counting all pixels on the capillary between the measuring points. The velocity of the moving hypofluorescent segments were calculated as $\mathrm{v}=\Delta \mathrm{s} / \Delta \mathrm{t}$. The assessment of the capillary flow velocities was performed in each patient in 15 different vessels. All measurements were performed in the monolayer capillary network preventing confounding errors from oblique vessels. The velocity of 10 different segments of low and high fluorescence in each capillary was quantified. Each value of the mean blood flow velocity (v) was based on 150 single measurements. All of these were performed within a time period of less than 5 seconds in the early transit phase of the angiograms. Measurements of actual distances were corrected for the refractive error. ${ }^{20}$ All angiograms were evaluated in masked fashion with no clinical data available.

All blood pressures and heart rates were recorded by automatic sphygmomanometry (Dinamap, Vital Daten Monitor 1846 Sx, Criticon, Tampa, FL, USA) immediately before each angiogram. Mean arterial blood pressure was calculated by adding one third of the pulse pressure to the diastolic pressure. Perfusion pressure was determined by subtracting the intraocular pressure from the mean arterial blood pressure.

\section{STATISTICS}

The Kolmogorov-Smirnov test was used to check normal distribution. Mean value and standard deviation are given for all samples. A repeated measures analysis of variance (ANOVA for repeated measurements) was calculated to evaluate the homogeneity of the baseline values and effects of the different treatments (systemic placebo/metipranolol; topical placebo/metipranolol). The hypothesis to test is that there are no differences between the effects of the four different treatments. The null hypothesis was rejected if the significance level was less than 0.05. Additional analysis using the Student's $t$ test was performed to identify differences between the mean values for the measurements before and after application of the test drugs. All $p$ values were adjusted for multiple testing according to Holm. ${ }^{21}$

\section{Results}

All 24 subjects completed the study and no side effects were observed after topical or systemic application of the test drugs. Baseline values at the four different sessions showed no significant differences (ANOVA for repeated 
Table 1 Values (mean (SD)) for the mean blood pressure, heart rate, and intraocular pressure (IOP) before and after application of the test drug

\begin{tabular}{|c|c|c|c|c|c|c|}
\hline & \multicolumn{2}{|c|}{$\begin{array}{l}\text { Mean blood pressure } \\
(\mathrm{mm} \mathrm{Hg})\end{array}$} & \multicolumn{2}{|c|}{ Heart rate (beats/min) } & \multicolumn{2}{|c|}{$I O P(m m ~ H g)$} \\
\hline & Before & After & Before & After & Before & After \\
\hline Topical placebo & $93(10)$ & $91(10)$ & $87(16)$ & $77(17)$ & $13(20$ & $12(2)$ \\
\hline Topical metipranolol & $92(9)$ & 93 (11) & $83(16)$ & $79(16)$ & $14(2)$ & $11(3)^{\star}$ \\
\hline Systemic placebo & $94(6)$ & $91(9)$ & $82(16)$ & $77(14)$ & $14(2)$ & $13(2)$ \\
\hline Systemic metipranolol & $93(8)$ & $87(9)^{\star}$ & $86(18)$ & $62(11)^{\star}$ & $13(2)$ & $10(2)^{\star}$ \\
\hline
\end{tabular}

*Significant differences between the mean values before and after application of the test drug; p<0.05; Student's $t$ test.

Table 2 Values (mean (SD)) for the arteriovenous passage time, the arterial mean dye bolus velocity, and the diameter of the temporal arteries before and after application of the test drug

\begin{tabular}{|c|c|c|c|c|c|c|}
\hline & \multicolumn{2}{|c|}{ Arteriovenous passage time (s) } & \multicolumn{2}{|c|}{$\begin{array}{l}\text { Arterial mean dye bolus } \\
\text { velocity }(\mathrm{mm} / \mathrm{s})\end{array}$} & \multicolumn{2}{|c|}{ Arterial diameter $(\mu \mathrm{m})$} \\
\hline & Before & After & Before & After & Before & After \\
\hline Topical placebo & $1.57(0.3)$ & $1.58(0.3)$ & $6.42(1.0)$ & $6.26(1.1)$ & $105(14)$ & $106(14)$ \\
\hline Topical metipranolol & $1.68(0.4)$ & $1.47(0.3)^{\star}$ & $5.97(1.4)$ & $6.70(1.0)^{\star}$ & $106(15)$ & $107(16)$ \\
\hline Systemic placebo & $1.56(0.3)$ & $1.45(0.3)$ & $6.34(1.3)$ & $6.81(1.2)$ & $106(15)$ & $107(13)$ \\
\hline Systemic metipranolol & $1.62(0.5)$ & $1.44(0.4)^{\star}$ & $6.28(1.5)$ & $6.90(1.2)^{\star}$ & $108(14)$ & $106(15)$ \\
\hline
\end{tabular}

^Significant differences between the measurements before and after application of the test drug; $\mathrm{p}<0.05$; Student's $t$ test.

measurements; $\mathrm{p}>0.24$ ). Mean values for the measurements of mean blood pressure, heart rate, and intraocular pressure are presented in Table 1.

Analysis of variance for repeated measures showed a significant therapy by pre/post interaction for the mean blood pressure (three factorial ANOVA for repeated measurements: $\mathrm{F}(1,23)=6.60 ; \mathrm{p}<0.05)$, heart rate (three factorial ANOVA for repeated measurements: $F$ $(1,23)=9.37 ; \mathrm{p}<0.01)$, and intraocular pressure (three factorial ANOVA for repeated measurements: $\mathrm{F}(1,23)=29.35 ; \mathrm{p}<0.01)$. Additional analysis (see Table 1) revealed a significant decrease of mean blood pressure, pulse rate, and intraocular pressure after systemic application of the test drug and a significant reduction of intraocular pressure after topical application of the drug.

Table 2 presents the mean values for the measurements of arteriovenous passage time, arterial mean dye bolus velocity, and vessel diameter of the temporal arteries. There was a significant effect on the arteriovenous passage time (three factorial ANOVA for repeated measurements: $F(1,23)=5.64 ; p<0.05)$ and the arterial mean dye bolus velocity (three factorial ANOVA for repeated measurements: F $(1,23)=7.87 ; \mathrm{p}<0.05)$. No effect on the arterial vessel diameter was observed. Further analysis (see Table 2) showed a significant increase of the arterial mean dye bolus velocity after topical as well as after systemic application of the $\beta$ adrenergic blocker. The arteriovenous passage time decreased significantly after application of the test drug (topical and

Table 3 Values (mean (SD)) for the capillary blood velocity and the perfusion pressure before and after application of the test drug

\begin{tabular}{llllll}
\hline & \multicolumn{2}{l}{ Capillary blood velocity $(\mathrm{mm} / \mathrm{s})$} & & \multicolumn{2}{c}{ Perfusion pressure $(\mathrm{mm} \mathrm{Hg})$} \\
\cline { 2 - 3 } & Before & After & & Before & After \\
\hline Topical placebo & $2.44(0.41)$ & $2.54(0.39)$ & & $49(7)$ & $48(7)$ \\
Topical metipranolol & $2.63(0.72)$ & $2.88(0.75)^{\star}$ & & $48(6)$ & $51(7)^{\star}$ \\
Systemic placebo & $2.52(0.24)$ & $2.51(0.30)$ & & $49(4)$ & $47(6)$ \\
Systemic metipranolol & $2.43(0.48)$ & $2.81(0.62)^{\star}$ & & $49(6)$ & $48(5)$
\end{tabular}

^Significant differences between the measurements before and after application of the test drug; $\mathrm{p}<0.05$; Student's $t$ test. systemic). Table 3 presents the mean values for the measurements of capillary blood velocity and the perfusion pressure. Analysis of variance for repeated measures showed a significant effect on the capillary blood velocity (three factorial ANOVA for repeated measurements: $\mathrm{F}(1,23)=40.45 ; \mathrm{p}<0.01)$ and the perfusion pressure (three factorial ANOVA for repeated measurements: $F(1,23)=6.51$; $\mathrm{p}<0.05)$. The capillary blood velocity increased significantly after both topical and systemic metipranolol.

No differences between topical and systemic application of the test drug on the blood flow measurements were observed. The perfusion pressure increased after topical application and remained unchanged after systemic application of metipranolol. No significant effects on any of the measurements were detected after application of placebo.

\section{Discussion}

Several techniques for measuring blood flow in the eye have been proposed. These include methods for assessment of total ocular blood flow, assessment of microcirculation of the optic nerve head, and measurement of retinal and choroidal blood flow. ${ }^{22-28}$ The method used in our study quantifies retinal circulation by measuring retinal flow velocities and circulation times. ${ }^{14}$

Recent studies emphasised the importance of vascular effects in the pathogenesis of glaucoma. ${ }^{29}{ }^{30}$ The impact of antiglaucomatous drugs on the ocular vasculature thus appears imperative. In this study, we investigated the acute effect after topical and systemic application of metipranolol, a non-selective $\beta$ adrenergic antagonist. The study was performed as double masked, randomised, placebo controlled crossover study with a washout time of 2 weeks after each session. The 2 week washout period is more than 50 times longer than the elimination half life of the drug in the body. To reduce further any potential crossover effect from drug to placebo we included 24 subjects 
in the study. This allowed us to use every possible sequence of the test drugs $(4 !=24)$.

After topical as well as after systemic administration of metipranolol we observed a significant decrease of the arteriovenous passage time in tandem with an increase of the arterial mean dye bolus velocity in healthy subjects. Arteriovenous passage time decreased by $13 \%$ after topical and by $11 \%$ after systemic application of metipranolol. The reduction of the arteriovenous passage time compares favourably with previous studies ${ }^{4}$ demonstrating a decrease of the arteriovenous passage time after topical timolol. The arterial mean dye bolus velocity increases after topical application of the test drug by $12 \%$ and after systemic application by $16 \%$. These results are comparable with findings of previous studies ${ }^{5} 9^{31-33}$ using laser Doppler techniques to assess retinal circulation. These studies showed an increase of flow velocities in retinal venules by $13 \%$ after topical application of timolol.

The increase of the arterial mean dye bolus velocity in tandem with the decrease of the arteriovenous passage time is equivalent with increased retinal blood flow if vessel geometry is unchanged. Our measurements demonstrated no change in diameter of the retinal arteries. This finding is supported by previous studies demonstrating no significant changes in retinal vessel diameters after $\beta$ adrenergic blockers. ${ }^{4}{ }^{67}$ In contrast with these studies, Martin and Rabineau $^{34}$ demonstrated a significant reduction in retinal vessel diameters $(4.1 \%)$ after chronic ( 7 days) application of timolol. However, the accuracy of measurements of retinal vessel diameters is relatively poor. Since the optical resolution of the eye is around $10 \mu \mathrm{m}$ only diameter changes of this magnitude are detectable with sufficient accuracy.

The flow velocities in the perifoveal capillaries increase after topical application of the test drug by $10 \%$ and after systemic application by $15 \%$. The similar change of flow velocities in retinal arteries and perifoveal capillaries shows that retinal circulation is enhanced equally at the capillary level and in larger retinal arteries.

The similarity between the effect of topical and systemic application of metipranolol on retinal circulation is interesting. Systemic nonselective $\beta$ adrenergic blocking agents are very likely to influence $\beta 2$ receptors in the eye, which have been shown to be present in the choroidal as well in the retinal vasculature ${ }^{35}$; however, there are very few in the retina. Since we were not able to demonstrate changes in retinal vessel diameters after systemic metipranolol, only a slight vasoconstriction of the retinal vessels can be expected after $\beta$ adrenergic blockage. Therefore, it is very unlikely that topical metipranolol acts as potential vasoconstrictor for retinal vessels, even if topically applied drugs diffuse through the cornea into the anterior chamber and, in some degree, to the retina and choroid. The penetration to the back of the eye of metipranolol is very likely, since this drug is lipophilic. In fact, it has been shown for similar drugs (for example, timolol) that after topical application retinal and choroidal concentrations of the drug equal those measured in the iris or ciliary body. ${ }^{36}$ However, the presence of the blood-retina barrier makes a direct pharmacological action of the drug very unlikely, since the medication in the blood cannot reach the smooth muscle of the retinal vasculature. This holds true equally for the systemic and topical metipranolol.

Therefore, changes in retinal circulation after metipranolol may be due to changes of intraocular pressure and not to local reactions of the retinal vasculature. This may be supported by recent studies showing enhancement of ocular circulation after filtering surgery in glaucoma patients. ${ }^{37}$ However, retinal circulation is autoregulated over a wide range of perfusion pressure. ${ }^{39}$ The autoregulatory response has been demonstrated directly after acute changes of the perfusion pressure only. To our knowledge no information about the effects of more chronic changes of the perfusion pressure is available.

The increase of retinal flow velocities may be caused be the significant increase of the retinal perfusion pressure after application of the $\beta$ adrenergic blocker. The perfusion pressure increases by $6 \%$ after topical application of metipranolol. However, the increase of the perfusion pressure is less pronounced than the change of retinal blood flow velocities. According to Hagen-Poiseuille's law changes in flow are proportional to changes of perfusion pressure. ${ }^{41}$ The discrepancy between the change of perfusion pressure and flow velocity as demonstrated in this study may be explained by the calculation of the perfusion pressure. For the calculation of the ocular perfusion pressure it is assumed that the mean arterial blood pressure in the ophthalmic artery is directly related to the systemic blood pressure. Previous studies measuring ophthalmic artery blood pressure showed a 5\%-10\% discrepancy of calculated and measured blood pressure in the ophthalmic artery. ${ }^{31}$ Probably, this may account for the discrepancy of increased flow velocity and the minimal decrease of the calculated perfusion pressure after systemic application of metipranolol.

Our data showing an increase in retinal circulation in healthy subjects contrast with previous studies measuring ocular pulsatile blood flow after timolol, ${ }^{42}$ another nonselective $\beta$ adrenergic blocking agent. The differences in the methods of measurement are one possible explanation. In the current study retinal circulation has been evaluated whereas previous studies measured pulsatile ocular blood flow determined in large part by choroidal blood flow. ${ }^{1}$ The effects of $\beta$ adrenergic blockers may differ in the retinal and choroidal vasculature, and so the results of current study are not comparable with measurements of ocular pulsatile blood flow.

Enhancement of retinal circulation may be relevant in glaucoma patients since ganglion body cells are located in the inner retina. They receive their metabolic supply from the retinal circulation. In patients with advanced glaucomatous damage the number of ganglion cells is markedly reduced which could be related to impaired retinal circulation. ${ }^{29}{ }^{42-44}$ Our findings 
also indicate that topical $\beta$ adrenergic blockers may have applications in the treatment of retinal circulatory deficiencies. ${ }^{45}$ Additional studies are needed to clarify the effects of $\beta$ adrenergic blockers on optic nerve head circulation, ${ }^{46}$ which may be of more importance than the retinal circulation in glaucoma patients.

Grant support: Deutsche Forschungsgemeinschaft Re 152/25 and Wo $478 / 5$ and by Dr Mann Pharma, Berlin, Germany.

The authors have no proprietary interest in any of the products discussed in this article.

1 Boles Carenini A. Differences in the long term effect of timolol and betaxolol on the pulsatile ocular blood flow. Surv Ophthalmol 1994;38(Suppl): 118-24.

2 Richard G, Weber J. Der Einfluß der Betablocker Timolol und Pindolol auf die retinale Hämodynamik- eine videoangiographische Studie. Klin Monatsbl Augenheilkd 1987;190: giograph.

3 Jay WM, Aziz MZ, Green K. Effect of topical epinephrine and timolol on ocular and optic nerve blood flow in phaki and aphakic rabbit eyes. Curr Eye Res 1984;3:1199-202.

4 Wolf S, Schulte K, Berg B, et al. Einflu $\beta$ von Beta-Blockern auf die retinale Hämodynamik: Doppelblindstudie be Gesunden. Klin Monatsbl Augenheilkd 1989;195:229-31.

5 Grunwald JE. Effect of topical timolol on the human retinal circulation. Invest Ophthalmol Vis Sci 1986;27:1713-19.

6 Yoshida A, Feke GT, Ogasawara $\mathrm{H}$, et al. Effect of timolol on human retinal, choroidal and optic nerve head circulation. Ophthalmic Res 1991;23:162-70.

7 Grunwald JE. Effect of timolol maleate on the retinal circulation of human eyes with ocular hypertension. Invest Oph thalmol Vis Sci 1990;31:521-6.

8 Chiou GCY, Yan H-Y. Effects of antiglaucoma drugs on the blood flow in rabbit eyes. Ophthalmic Res 1986;18:265-9.

9 Gupta A, Chen HC, Rassam SMB, et al. Effect of betaxolo on the retinal circulation in eyes with ocular hypertension: a pilot study. Eye 1994;8:668-71.

10 Langham ME, Boles Carenini B, Brogliatti A, et al. Differences in the actions of timolol and betaxolol on vision and ocular pulsatile blood flow in glaucoma (abstract). Invest Ophthalmol Vis Sci 1993;34(Suppl):1287.

11 Phillips CI, Howitt G, Rowlands DJ. Propranolol as ocular hypotensive agent. Br f Ophthalmol 1967;51:222-6.

12 Abshagen U, Betzien G, Kaufmann B, et al. Pharmacokinetics of metipranolol in normal man. Eur $\mathcal{F}$ Clin Pharmaco 1982;21:293-301.

13 Krieglstein GK, Novack GD, Voepel E, et al. Levobunolol and metipranolol: comparative ocular hypotensive efficacy, and metipranolol: comparative ocular hypotensive efficact

14 Wolf S, Arend O, Reim M. Measurement of retinal hemodynamics with scanning laser ophthalmoscopy: reference values and variation. Surv Ophthalmol (Suppl) 1994;38:95 100 .

15 Toonen H, Wolf S, Jung F, et al. Bewegungskorrektur von digitalen Sequenzangiographien der Netzhaut. Biomed Tech 1992;37:131-6.

16 Brinchmann-Hansen O, Engvold O. Microphotometry of the blood column and the light streak on retinal vessels in fundus photographs. Acta Ophthalmol Suppl 1986;179:919.

17 Brinchmann-Hansen O, Heier H, Myhre K. Fundus photography of width and intensity of the blood column and the light reflex in retinal vessels. Acta Ophthalmol 1986; and the light

18 Rassam SMB, Patel V, Brinchmann-Hansen O, et al. Accurate vessel width measurement from fundus photographs: a new concept. Brf Ophthalmol 1994:78:24-9.

19 Toonen F, Harris A, Arend O, et al. The effect of oxygen on retinal hemodynamics and vascular diameters. Clin Hemorh 1994;15:257

20 Littmann H. Zur Bestimmung der wahren Größe eines Objektes auf dem Hintergrund eines lebenden Auges. Klin Monatsbl Augenheilkd 1988;192:66-7.

21 Holm S. A simple sequentially rejective multiple test procedure. Scand $\mathcal{F}$ Stat 1979;6:65-70.
22 Ulrich WD, Ulrich C, Bohne BD. Deficient autoregulation and lengthening of the diffusion distance in the anterior optic nerve circulation in glaucoma: an electro-encephalodynamographic investigation. Ophthalmic Res 1986;18 253-9.

23 Riva CE, Feke GT, Eberli B, et al. Bidirectional LDV system for absolute measurement of blood speed in retinal vessels. Appl Optics 1979;18:2301-6.

24 Riva CE, Petrig B. Blue field entoptic phenomenon and velocity in the retinal capillaries. F Opt Soc Am 1980;70: 1234-8.

25 Wolf S, Jung F, Kiesewetter $\mathrm{H}$, et al. Video fluorescein angiography: method and clinical application. Graefes Arch Clin Exp Ophthalmol 1989;227:145-51.

26 Schwartz RW, Freedman AM, Richardson DR, et al. Videodensiometry in the microcirculation in the arterosclerotic patient: capillary blood flow. F Vasc Surg 1984;1:800

27 Nagin P, Schwartz B, Reynolds G. Measurement of fluorescein angiograms of the optic disc and retina using computerized image analysis. Ophthalmology 1985;92:547-52.

28 Klein GJ, Baumgartner RH, Flower RW. An image processing approach to characterizing choroidal blood flow. Invest Ophthalmol Vis Sci 1990;31:629-37.

29 Wolf S, Arend O, Sponsel WE, et al. Retinal hemodynamics using scanning laser ophthalmoscopy and hemorheology in chronic open-angle glaucoma. Ophthalmology 1993;100: 1561-6.

30 Harris A, Sergott RC, Spaeth GL, et al. Color doppler analysis of ocular vessel blood velocity in normal-tension glaucoma. Am F Ophthalmol 1994;118:642-9.

31 Grunwald JE, Furubayashi C. Effect of topical timolo maleate on the ophthalmic artery blood pressure. Invest Ophthalmol Vis Sci 1989;30:1095-100.

32 Grunwald JE. Effect of two weeks of timolol maleate treatment on the normal retinal circulation. Invest Ophthalmol Vis Sci 1991;32:39-45.

33 Chen S, Robinson F, Pettrig BL, et al. The acute effect of topical timolol on human macular capillary blood flow. Invest Ophthalmol Vis Sci (Suppl) 1993;34:1394.

34 Martin XD, Rabineau PA. Vasoconstrictive effect of topical timolol on human retinal arteries. Graefes Arch Clin Exp Ophthalmol 1989;227:526-30.

35 Denis P, Elena PP. Récepteurs bêta-adrénergiques vasculaires rétiniens chez l'homme. Ophthalmologie 1989;3:62-4.

36 Schmitt CL, Lotti VJ, LeDouarec JC. Penetration of timolol into the rabit eye: measurements after ocular installation and intravenous injection. Arch Ophthalmol 1980;98:54751 .

37 James CB. Effect of trabeculectomy on pulsatile ocular blood flow. Br f Ophthalmol 1994;78:818-22.

38 Wolf S, Arend O, Haas A, et al. Retinal hemodynamics in patients with chronic open-angle glaucoma. Ger f Ophthalmol 1995;4:279-22.

39 Riva CE, Sinclair SH, Grunwald JE. Autoregulation of retinal circulation in response to decrease of perfusion pressure. Invest Ophthalmol Vis Sci 1981;21:34-8.

40 Hagen $\mathrm{G}$. Über die Bewegung des Wassers in engen zylindrischen Röhren. Poggendorf's Annalen der Physik und Chemie 1839;46:423.

41 Poiseuille JML. Recherches experimetales sur le mouvement des liquides dans les tubes de tres petits diametres. Comp rend 1842;15:1167.

42 Langham ME. Ocular blood flow and vision in healthy and glaucomatous eyes. Surv Ophthalmol 1994;38(Suppl): $161-8$

43 Grunwald JE, Riva CE, Stone RA, et al. Retinal autoregulation in open-angle glaucoma. Ophthalmology 1984;91: 1690-4.

44 Hamard P, Hamard H, Dufaux J. Blood flow rate in the microvasculature of the optic nerve head in primary open angle glaucoma. A new approach. Surv Ophthalmol 1994;38(Suppl): $87-94$.

45 Wolf S, Hoberg A, Bertram B, et al. Videofluoreszenzangiographische Verlaufsbeobachtungen bei Patienten mit retinalen Arterienverschlüssen. Klin Monatsbl Augenheilkd 1989;195:154-60.

46 Cantor LB, Harris A, Wolf S, et al. Measurement of superficial optic nerve head capillary blood velocities by scanning laser fluorescein angiography. F Glaucoma 1994;3(Supp 1):S61-4. 